\title{
Does the Unavailability of Educational Resources in Schools Determine Child Labor in Sub-Saharan Africa? A Micro-econometric Analysis from Côte d'ivoire
}

\section{Pokou Edouard Abou*}

University of Felix Houphouet Boigny, Abidjan, Côte d'Ivoire

\begin{abstract}
Child labor remains a concern for policy makers considering its interrelations with human capital formation. Indeed, in Sub-Saharan Africa and particularly in Cote d'Ivoire, children are still on the labor market. Several factors explain this fact of setting children to work. Given this diversity of determinants of child labor, this study aims to show the effects of school resources on child labor. Therefore, we use the 2010 national survey data on child labor and education policies. From a bivariate probit model, the results showed that the availability of certain school resources as a canteen and a drinking water point in the school promotes the education of children and especially girls. On the contrary, their unavailability forces parents to put their children on labor market. Therefore, one of the major policies to be implemented is to improve the learning environment of children by building school canteens and drinking water point in schools. It's a new challenge for policy makers to effectively fight against child labor and reach the goal of education for all and of quality in 2030.
\end{abstract}

Keywords: Child labor; Educational resources; Bivariate probit; Micro-econometric; Poverty

\section{Introduction}

Ensuring an education of quality and provide learning opportunities is one of the sustainable development gold. But in Sub Saharan Africa countries, the prevalence of child labor can be a barrier to achieving this goal. Indeed, all areas in the world have experienced a significant decline in child labor rates unless the Sub Saharan Africa countries [1]. In 2012, this area recorded $21.7 \%$ of child workers compared with other regions where it remains low (8.3\% in Asia and the Pacific, $7.2 \%$ in Latin America and the Caribbean and $4.8 \%$ in other regions).

In Cote d'Ivoire, the problem of child labor is a major concern for years and generates debate in socio-political environments. Therefore, this issue is the subject of discussion among scientists [1-4]. Moreover, various studies from surveys have shown the extent of child labor. In 2008, the results of the survey living standards of households reported a participation rate of children aged 5-13 years at $20.8 \%$ [5]. Recently, the national survey on the situation of employment and child labor 2013 (ENSETE 2013) showed that 20.9\% of children aged 5-13 years were economically active [6]. These rates of labor imply that some children are deprived of educational opportunities. But this one, favoring the growth of education appears as a way to reduce inequality [7]. Moreover, it is hard for these inequalities for some authors; child labor perpetuates poverty from generation to generation [8].

In the literature, several studies have identified the determinants of child labor [9-12]. Among these causes, income poverty is considered the most critical. However, empirical studies have shown that the relationship between this variable and the development of child labor is mixed $[13,14]$. In other words, income poverty does not by itself explain child labor. Moreover, in some poor households, child labor is seen as a survival strategy [9]. Although other studies explain child labor by the lack of parental resources to finance the education of children [15], note that these studies complete those that highlight income poverty. To account for other factors that could influence the reduction of child labor, the authors attempt to shed light on the importance of school resources on improving student scores $[15,16]$. Unfortunately, in Côte d'Ivoire, there are few studies that consider these resources in the analysis of child labor. However, their availability in schools can reduce school failure [17]; which would promote all things being equal the reduction of child labor.

In recent years, the education system in Côte d'Ivoire is marked by weak external returns. These revolve around the high rate of unemployment among higher education graduates $[6,18]$. Moreover, increasingly, in the education system, educational facilities become insufficient to such an extent that they affect the quality of education. These weaknesses could encourage parents to put their children on labor market. It is therefore important to consider school resources in the analysis of child labor. Thus, the objective of this study is the demonstration of the effects of the unavailability of school resources on child labor to reorient policies to performance and retention of students in school.

\section{Literature Review}

The basic theory on child labor is the one of Basu and Van [19]. This theory based on income poverty, provides an explanation of child labor. These authors call this theory luxury axiom or strong hypothesis. This luxury axiom stipulates that households have altruistic behavior. Indeed, sending children on the labor market depends on parental income. So when that income without the contribution of the children falls below the subsistence level, then the parents put children on the labor market. This implies that these parents withdraw their children from work when their income would allow them to meet household needs. In fact, the goal of parents is to maximize the utility of the household. Accordingly, as long as economic conditions permit parents to meet household needs, children, they can devote themselves

*Corresponding author: Pokou Edouard Abou, University of Felix Houphoue Boigny, Abidjan, Côte d'Ivoire, Tel: (+225) 09929193; Fax: (+225) 22422724; E-mail: aboued2000@yahoo.fr

Received March 03, 2015; Accepted March 10, 2016; Published March 14, 2016

Citation: Abou PE (2016) Does the Unavailability of Educational Resources in Schools Determine Child Labor in Sub-Saharan Africa? A Micro-econometric Analysis from Côte d'ivoire. Int J Econ Manag Sci 5: 326. doi:10.4172/2162 6359.1000326

Copyright: (c) 2016 Abou PE. This is an open-access article distributed under the terms of the Creative Commons Attribution License, which permits unrestricted use, distribution, and reproduction in any medium, provided the original author and source are credited. 
to studies and recreation. However, if the household is vulnerable or is impacted, (death of the head of household, loss of employment of the household head, etc.) parents will resort to child labor to maintain the standard of living of the household. Thus, on the basis of parents' altruism hypothesis, the fact of setting children to work is a household survival strategy. This is also what the study of some authors confirmed in the case of Sierra Leone [9]. Indeed, because of their vulnerability, these authors showed that the income of children taken from their work contributes to the improvement of the living conditions of poor households in Sierra Leone. Thus, depriving work makes children depriving children of work even more vulnerable Sierra Leonean households.

In literature, several studies have highlighted the luxury axiom [20-22]. For example, in rural areas of Tanzania, child labor becomes dominant over a period of three years as the household becomes poor [23]. In Cote d'Ivoire, the studies to highlight this hypothesis exist. They generally come from life level household survey [1-4]. However, it is important to note that simply to show that the income negatively affects children's labor supply cannot be interpreted as evidence that the strong hypothesis of poverty is valid. Indeed, some author found little robust results [1]. Besides, most of these studies do not take into account the school resources to allow some comparison. But Cote d'Ivoire aspires to emerge in 2020. This means that all children should attend schools which benefit from a favorable environment for their development and retention in the education system.

Since the publication of the report of Coleman et al. [24], the quality of education has become a concern for policy makers. The concern at the center of studies is including the consideration of the effects of this quality on the academic performance of students [25]. It can be understood in two ways: macroeconomic and microeconomic aspects. The first is based on the estimation of production functions from aggregated data [26,27]. The second takes account of the relationship between student performance and teaching environment that is, firstly the characteristics of schools and secondly, institutional arrangements [28]. In other words, there is a proper environment for learning. Thus, the learning environment of children becomes a requirement. This environment is characterized by the availability of educational resources in the school. Indeed, school outcome studies of children have been analyzed in terms of family background [29]. Naturally, these works reflect poverty, demographics, etc. Naturally, the school environment can influence student performance $[8,16]$. Indeed, the availability of school resources (school canteen, toilets, drinking water, electricity, library, playground, sports equipment, etc.) could significantly improve the school results of children and promote their retention in the education system.

Several studies have evaluated the impact of these resources on education and child labor $[8,16,17]$. In their approach, some authors identify two types of school resources. These are physical resources and resources for teachers [8]. The first type of resource considers ten indicators: i) construction of concrete school; ii) access to electricity; iii) supply of water; iv) access to toilets; v) no partition in the classroom; vi) no multi-level class; vii) classroom availability; viii) no movement or classroom canceled because of rain; ix) availability in a usable blackboard and $\mathrm{x}$ ) availability of a library. The second type of resource includes eight indicators: i) a room for teachers; ii) lockers for files; iii) a telephone; iv) a typewriter; v) access to a computer; vi) chalk; vii) pens, pencils and crayons and viii) paper. His multivariate analysis shows that most children attend a school with electricity. This analysis indicates that the effects of school resources may vary from one place to another, from one region to another and from one country to another. Indeed, many of these resources have not yielded significant results.

In Sri Lanka, the presence of toilets, of drinking water points, electricity and school canteens promotes children's performance in school [17]. In their analysis, these authors ignore the household characteristics. For their part, other author in the case of Ghana will contribute to the debate taking into account school resources and household characteristics [16]. Their results from a hierarchical linear model show that class size and the presence of toilets improves more student scores in some subjects such as English. In Cote d'Ivoire, many schools do not have school resources. The objective for policymakers is to send as many children to school to prevent them from being on the labor market. The focus is usually on quantity and not quality, or you need a combination of both. Indeed, [29] in the case of Guatemala from data on schools, teachers and classrooms shows the importance of student success in rural areas through the availability of educational resources in schools. In other words, the availability of these resources in schools can be an asset in the fight against child labor.

\section{Methodology and Data}

\section{Theoretical model}

The research question in this analysis is to know what school resource that promotes the education of children and reduce their work. Therefore, we appeal to the theory of the characteristics of goods [29]. Indeed, people act so that their decision is the one that gives them the greatest utility. This one is the characteristics of the good consumed. As opposed to the traditional approach that considers the goods as direct objects of utility, Lancaster [30] assumes that the value derived properties or characteristics of those goods.

In this analysis, we use the model of Bacolod and Ranjan [8]. Indeed, our model describes householders living in decision making. They face a whole range of activities (school, work) for their children in light of school characteristics (resources available in schools). Therefore, the utility of the household head will therefore depend on the current consumption $(\mathrm{C})$ and human capital $(\mathrm{H})$ of the child. This level of human capital is function of the resources available in the school $(\varphi)$ and child characteristics $(\sigma)$, then:

$$
\mathrm{H}=\mathrm{h}(\varphi, \sigma)
$$

Every child has a unit of time that the head of household sharing between work (l) and school (e). Here, we do not take into account leisure. We assume that it is part of the child's education. Thus the child's time constraint is:

$1+e=1$

While working, the child receives a salary (W) per unit of time worked. Moreover, when the child goes to school for the acquisition of human capital, the head of household must bear a direct cost of schooling. This cost is proportional to the time spent at school. It is represented by (d.e). Children's schooling is funded from the head of household income (y). Besides parental income, the child who works as a shot of his labor income (wl). In reality, it is part of the income of the household consumer strategy. The budget constraint is:

$$
\mathrm{C}=\mathrm{y}+\mathrm{wl}-\text { d.e }
$$

The objective of the household head is to maximize the following utility function:

$$
\mathrm{U}=\mathrm{u}(\mathrm{C}, \mathrm{H})
$$


subject to (2) and (3)

The result of this program is:

$\mathrm{l}^{*}(\mathrm{y}, \mathrm{wl}, \varphi, \sigma)$

$\mathrm{e}^{*}(\mathrm{y}, \mathrm{wl}, \varphi, \sigma)$

This equation (5) shows that the choice of children's activities is income (y) of the head of household, the children (wl), school resources $(\varphi)$ and individual characteristics of children $(\sigma)$.

\section{Empirical model}

From our sample, it is not always possible to have information on the number of hours of excessive child labor. So we see children working or attending school in the district, village, etc. Thus, Figure 1 below shows the participation of children in work and school.

Figure 1 shows a labor participation equation (EQUATION 1) and another at school (EQUATION 2). These two equations allow to empirically testing the results of the theoretical model (5). Indeed, the head of household decides to put her child to work or not. This decision is based on certain characteristics (characteristics of head of household, school characteristics, characteristics of children). Note that the definition of child labor is sometimes ambiguous and not shared by the research community [30]. However, in this study, this concept is defined by the dangerous nature of the work contained in the law n.009 of 12 January 2012 determining the list of hazardous work prohibited to children under 18 years (Table A1 of Appendix).

Both equations 1 and 2 can be identified by an estimated bivariate probit model. In developing countries, several studies using this model [31]. The advantage of this is that it examines the relationship between children's schooling and work in both directions. In other words, this model tests the probability for children to work and or go to school. Its validation assumes that the coefficient of correlation between the error terms is significantly negative. Otherwise, unobserved factors that increase the probability of attending school decrease the work. Indeed, this model allows for correlations in terms of regression errors between schooling and child labor. It can be effective when the bivariate normal errors are checked.

Formally, this model is as follows: Let ' $W$ ', working with $W=1$ if the child works and 0 if not. Identically, schooling is denoted by ' $S$ ' with $S$ $=1$ if the child attends school and 0 if not. These two variables $(\mathrm{W}, \mathrm{S})$ are not observed. They are explained by the linear combinations $\mathrm{X}_{1}$ and $\mathrm{X}_{2}$ (Greene). Thus:

$$
\begin{aligned}
& \mathrm{W}=\mathrm{X}_{1} \beta_{1}+\varepsilon_{1}, \mathrm{~W}=1 \text { si } \mathrm{W}>0,0 \text { si non } \\
& \mathrm{S}=\mathrm{X}_{2} \beta_{2}+\varepsilon_{2}, \mathrm{~S}=1 \text { si } \mathrm{S}>0,0 \text { si non } \\
& \text { with: }\left(\begin{array}{l}
\varepsilon_{1} \\
\varepsilon_{2}
\end{array} \mid X_{1}, X_{2}\right)_{\sim} N\left[\left(\begin{array}{l}
0 \\
0
\end{array}\right),\left(\begin{array}{ll}
1 & \rho \\
\rho & 1
\end{array}\right)\right]
\end{aligned}
$$

Where $\mathrm{X}_{1}$ and $\mathrm{X}_{2}$ are the predictors of row vectors which respectively determine the propensity to put children to work or into school. $\beta_{1}$ and $\beta_{2}$ indicate the column vectors of the parameters associated with the two equations. $\rho$ identifies the correlation between the error terms. This equation will be estimated by the method of maximum likelihood under the STATA software.

\section{Data}

This study uses the 2010 local survey data on child labor and education policy (ELTEPE 2010). With the support of the Strategic
Support Program for Scientific Research in Cote d'Ivoire (PASRES), these data were collected in the towns of Bouake and Soubre with different socioeconomic realities.

Located in the southwest of Cote d'Ivoire, Soubre is one of the largest cocoa producing areas. In this area, the proportion of children in child labor category is important according to the 2005 national survey on child labor $(35.8 \%)$. As for the town of Bouake, it is located in the center of the Cote d'Ivoire with a large proportion of child labor [4]. Both localities like others benefit from programs initiated by governments since the 2000 s to promote an increase in the enrollment rate. These include the increase in classrooms, the school resource endowment of schools, etc. The survey stratified sample with two degrees allowed to take account of educational policies to fight against child labor. First degree, census districts are drawn and the second degree, a fixed number of households is selected. Thus, a sample of 750 households and 1,338 children are our sample.

From this sample, we have information on a range of variables. We recall that as disclosed in the specification of the model (EQUATION 6), there are two dependent variables: WORK (W) and SCHOOL (S).

Table 1 shows that overall; around $70 \%$ of children attend school only against $10.99 \%$ who are compelled to work. By sex, the proportion of women at work is higher (13.88\%). Note that some of these children are neither working nor in school (15.84\%). In reality, these children may be at work but their activities do not fall into the category of child labor.

Besides the two dependent variables, we have the independent variables (Table A2 in Appendix).

To evaluate household living conditions, we consider the average

\section{PARTICIPATION MODEL FOR CHILDREN WORK AND SCHOOL}

During the las 7 days have you urderlaker any of the following? Cullivale or harvest crops; prepare food clean the house; repair tools or equipment to someone else against payment in kind or in cash; washing cars, shoe shime; freight transport market; garhage search; constrnction, building maintenance, etc

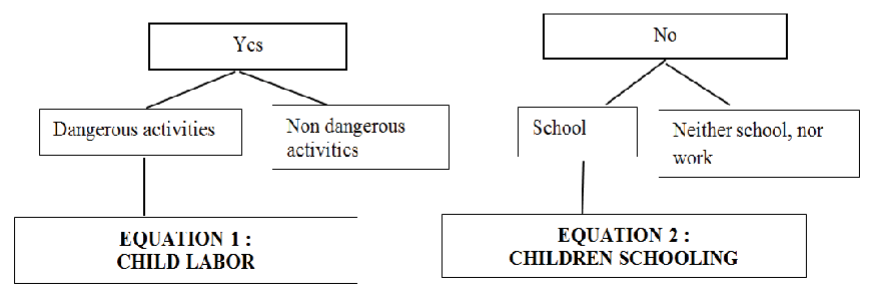

Source: Author

Figure 1: Model explaining the participation of children of $6-13$ years in work or in school.

\begin{tabular}{|c|c|c|c|c|}
\hline Sex & School only & $\begin{array}{c}\text { School and } \\
\text { work }\end{array}$ & Work only & $\begin{array}{c}\text { Neither school } \\
\text { nor work }\end{array}$ \\
\hline Boys & 72.94 & 7.44 & 7.75 & 11.87 \\
\hline Girls & 61.05 & 5.67 & 13.88 & 19.41 \\
\hline Whole & 66.87 & 6.5 & 10.99 & 15.84 \\
\hline
\end{tabular}

Source: Our calculations from the data ELTEPE 2010

Table 1: Proportion of children 6-13 years by activity. 
expenditure per head. (dep_m). This choice is based on the fact that our societies are characterized by self-employment households, a predominance of subsistence agriculture and informal employment. In addition, directly use the income does not capture the economic situation of the household. In addition, households do not like to reveal their income. As shown in Table A2 in Appendix, the average household expenditure per capita is estimated at 156362 FCFA per year. It is less than the poverty rate [32]. This assumes that households are generally poor. Moreover, the level of education of the household head is important. The more this level, the fewer children are placed on the labor market $[1,11]$. Unfortunately, statistics show that most children live in households where the heads are without level of education (48.04\%).

In this study, the following school resources are taken into account. It is the availability of: toilet, canteen, point of drinking water, electricity and classrooms. The last variable is measured by the size of the class (ratio teacher / student). It's important is that despite the sometimes contradictory results, reduced class sizes could be more conducive to improving children's performance [33]. Analysis of Table A2 in Appendix shows that apart from electricity, other resources are less available in schools (water, $31.24 \%$; toilet, $47.46 \%$; canteen, $36.25 \%$ ). In addition, on average, there are 46 students per class.

In addition to school resources, specific to the child characteristics are also taken into account. Indeed, they can influence putting to the labor market. In this study, we therefore take into account the age and sex of the child.

\section{Econometrics results}

In this analysis, the estimated bivariate probit provides directly the likelihood ratio test that has a distribution chi(2) with 1 degree of freedom (Table A3 in Appendix). Thus, at a 1\% level, the null hypothesis which indicates that there is no correlation is dismissed. This correlation between the terms of the error confirms the choice of the bivariate probit model. Overall, the null hypothesis that all coefficients are zero is rejected (prob $>$ chi $2=0.0000$ ). Furthermore, the correlation between the error terms (Rho) was significantly negative to a threshold of $1 \%$. In other words, unobserved factors that increase the probability of working reduce those to attend school regardless of the sample. Thus, when the income of the household head increases the probability of school enrollment increases (0.05) while the work decreased $(-0.030)$. However, by gender, income growth positively affects the schooling of girls. In other words, in general, these results confirm the luxury axiom as those found in the literature $[1,3,4]$. Nevertheless, the odds are low. In addition, these results indicate the importance of the level of the household head in explaining the choice of children's activities. Indeed, an increase in the level of education of the household head increases the chances of education for children and reduces that of working regardless of gender. Unlike the income, the probabilities are higher with the level of education. This confirms the explanatory power of education in the analysis of child labor [8].

Overall, the estimation of school resources has given the expected results. Indeed, their availability in the school promotes the education of children and reduces their setting to work. Specifically, the availability of canteen in the school greatly increases the probability of school enrollment. This probability is higher among girls (0.416) than boys (0.219). One explanation is that the presence of canteen in the school allows children to have a lunch. They are not obliged to come home and thus avoiding additional transport costs to parents and sometimes displacements on long distances to the children themselves. In addition to the canteen, where there is electricity in the school, the likelihood of labor reduces overall [8]. By sex, this source of energy in the school promotes the education of girls and boys and reduces their work. In addition, the availability of a drinking water point in the school also increases the chances of education for children, particularly those of boys. Indeed, culturally, the search of water especially in rural areas is a task devoted to girls. However, in primary schools, where there is no drinking water point, all students (girls and boys) are in charge of supplying teachers with water. Thus, the existence of drinking water point in the school encourages parents to send their boys to school.

In sum, these results confirm the importance of school resources in the analysis of child labor. We note that several studies have confirmed our results $[16,17]$.

Apart from the above results, the bivariate probit model shows that when the child is a girl, she is more likely to be on the labor market. Moreover, the probability of school enrollment increases initially with age and then decreases. This reflects the fact that parents prefer to educate younger children. In reality, children perform manual and physical tasks. Therefore, the higher the age, the more they are able to work $[34,35]$.

\section{Conclusion}

This article was intended to highlight the effects of school resources on child labor in Cote d'Ivoire. Given the debate on the definition of child labor, this analysis defines the concept in relation to hazardous work. Thus, from a micro-econometric analysis based on local survey data on child labor and educational policies (ELTEPE 2010), this study gave several results. Indeed, apart from the traditional factors (income, education level, child-specific characteristic), this study showed that school resources positively influence the education of children but influence negatively the development of working children. Specifically, the canteen availability in schools greatly increases the probability of school enrollment. Thus, to promote the education of children and reduce child labor significantly, policymakers should focus on improving children's learning. This policy requires the equipping of primary schools with school canteens, with drinking water points and with electricity.

\section{References}

1. Diallo $Y(2001)$ Children and their participation in the labor market in Côte $d^{\prime}$ Ivoire, PhD Thesis. University of Bordeaux, Bordeaux IV, France.

2. Abou PE (2014) Education and Child labor in Ivory Coast, (1stedtn) European University, Saarbrücken, Germany.

3. Nkamleu GB (2009) Determinants of Child Labour and Schooling in the Native Cocoa Households of Côte d'Ivoire. Research Paper no.190, African Economic Research Consortium, Nairobi, Kenya.

4. Grootaert C (1998) Child labour in Côte d'Ivoire: incidence and determinants World Bank, Washington, DC.

5. INS (2010) Child labor in the Ivory Coast from the survey on the living standards of households. National Institute of Statistics , Abidjan , Ivory Coast

6. INS (2014) National survey on the situation of employment and child labor National Institute of Statistics, Abidjan, Ivory Coast.

7. Becker GS (1975) Human capital: A theoretical and empirical analysis with special reference to education. University of chicago press, Chicago, USA

8. Bacolod M, Ranjan P (2008) Why Children Work, Attend School, or Stay Idle: The Roles of Ability and Household Wealth. Economic Development and Cultural Change 56: 791-828.

9. Maconachie R, Galvin H (2016) Re-Thinking the Child Labor "Problem" in Rural Africa: The Case of Sierra Leone's Half Shovels. World Development 78: 136147. 
Citation: Abou PE (2016) Does the Unavailability of Educational Resources in Schools Determine Child Labor in Sub-Saharan Africa? A Micro-econometric Analysis from Côte d'ivoire. Int J Econ Manag Sci 5: 326. doi:10.4172/2162-6359.1000326

Page 5 of 5

10. Lachaud JP (2008) Child labor and poverty in Africa: a review applied in Burkina Faso. Economics and Forecasting 5: 47-65.

11. Okpukpara B, Odurukwe N (2006) Incidence and determinants of child labour in Nigeria: implications for poverty alleviation. Research Paper, no.156. African Economic Research Consortium Nairobi, Kenya.

12. Bhalotra S (2007) Is child work necessary? Oxford Bulletin of Economics and Statistics 69: 29-55.

13. Ray R (2000) The determinanant of child labour and child schooling in Ghana Journal of african Economies 13: 561-590

14. Baland JM, Robinson, J (2000) Is child labour inefficient? Journal of Political Economy 108: 663-679.

15. Gina, AC, Rainier, DM, Yalitza R, David A (2015) How do student and schoo characteristics influence youth academic achievement in Ghana? A hierarchical linear modeling of Ghana Youth Save baseline data. International Journal of Educational Development 45: 129-140.

16. Aturupane H, Glewwe P, Wisniewski S (2013) The impact of school quality, scoioeconomic factors, and child health on students' academi performance: Evidence from Sri Lankan primary schools. Education Economics 21: 2-37.

17. Kouakou K (2008) Determinant of urban youth labor supply in Côte d'Ivoire. African Journal of Economic Policy 15: 29-57.

18. Basu K, Van H (1998) The Economics of Child Labor. American Economic Review 17: 412-427

19. Putnick L, Bornstein M (2015) Is child labor a barrier to school enrollment in low-and middle-income countries? International Journal of Educational Development 41: 112-120.

20. Edmonds E (2005) Does Child Labor Decline with Improving Economic Status. The Journal of Human Resources 19: 77-99.

21. Ersado L (2005) Child Labor and Schooling Decisions in Urban and Rura Areas: Comparative Evidence from Nepal, Peru, and Zimbabwe. World Development 33: 455-480.

22. Beegle K, Dehejia R, Gatti, R (2006) Child labor and agricultural shocks. Journal of Development Economics 13: 80-96.
23. Coleman JS, Ernest QC, Carol JH, James Mc, Alexander MM, et al. (1976) Equality of educational opportunity. National Center for Educational Statistics, Washington, DC, USA

24. Hanusheck $E$ (2003) The failure of input-based schooling policies. Economic Journal 113: 64-98

25. Lee J W, Barro R (2001) Schooling quality in a cross-section of countries. Economica 68: 465-488

26. Hanusheck E, Kimko D (2000) Schooling, labor-force quality, and the growth of nations. American Economic Review 31: 1184-1208.

27. Wobmann L (2003) Schooling Resources, Educational Institutions and Studen Performance: The International Evidence. Oxford Bulletin of Economics and Statistics 65: 17-170.

28. Jeffery HM (2011) School quality signals and attendance in rural Guatemala. Economics of Education Review 30: 1445-1455.

29. Lancaster KJ (1966) A new approach to consumer theory. The Journal of Political Economy 74: 132-137.

30. Das S, Deb R (2006) A dynamic analysis of child labour with a variable rate of discount: Some policy implications. The B.E Journal of Economics Analysis 5. $1-30$

31. Zapata D, Dante C, Kruger D (2011) Child labor and Schooling in Bolivia: Who's Falling behing? The Roles of Domestic Work, Gender, and Ethnicity. World Development 30: 588-599.

32. INS (2015) Survey of households living in Ivory Coast. National Institute of Statistics, Abidjan, Ivory Coast.

33. Krueger A (2003) Economic Considerations and Class Size. Economic Journa 113: 34-63.

34. Abou, PE (2014b) A Re-examination of the Determinants of Child Labour in Côte d'Ivoire. Reseach Paper, no.289, African Economic Research Consortium Nairobi, Kenya. Research Paper no.289.

35. Blunch NH, Verner D (2000) Revisiting the Link between Poverty and Child Labor: The Ghanaian Experience. The World Bank, Washington, DC, USA. 


\section{Appendixes}

\begin{tabular}{|c|c|}
\hline Hazardous types of work & Localization \\
\hline Agriculture and Forestry & \multirow{7}{*}{ National territory } \\
\hline Felling of trees; & \\
\hline Burning of fields; & \\
\hline Spreading of chemicals (insecticide, weed killer, fungicide, etc.); & \\
\hline Spreading of chemical fertilizers; & \\
\hline Chemical treatment of seedbeds; & \\
\hline Carrying of heavy loads & \\
\hline In the breeding & \multirow{4}{*}{ National territory } \\
\hline The traditional harvest honey; & \\
\hline The activities of child herders; & \\
\hline Slaughter of animals operations & \\
\hline In fishing & Area lagoons \\
\hline Marine fisheries on the lagoon or on the rivers; & coastal areas \\
\hline Diving in deep water. & river regions \\
\hline In the domestic urban sector & \multirow{3}{*}{ National territory } \\
\hline Caretaking; & \\
\hline Work in drinking establishments (nightclubs, bars, restaurants, etc.) & \\
\hline In trading & \multirow{7}{*}{ National territory } \\
\hline The sale of pornographic support; & \\
\hline The prostitution or sex trafficking; & \\
\hline The recovery of items in landfills; & \\
\hline Emptying the pre-collection and collection of household waste; & \\
\hline $\begin{array}{l}\text { Production, purchase or sale of chemical products (traditional medicines } \\
\text { or not, detergents ...) }\end{array}$ & \\
\hline Porters activities in markets & \\
\hline In industry and crafts & \\
\hline Lubrication, cleaning, visiting or repairing machines or mechanisms on; & \\
\hline $\begin{array}{l}\text { The adjustment, grinding, emptying, grinding, milling, rolling, downhill } \\
\text { engine, handling batteries; }\end{array}$ & \\
\hline The manufacture or repair of firearms; & \\
\hline The manufacture and handling of explosives; & \\
\hline
\end{tabular}


The motorized sanding leather and tanning the skin;

The dyeing and printing

The planning mechanized and chemical treatment and mechanical wood;

Ginning and spinning;

The production of drugstore (detergents: liquid soap making, bleach, etc.);

The brewery and alcohol production;

The boiler;

Handling all hydrocarbons and flammable products;

Work in the forge (plowing manufacturing materials such daba, knives ...)

The ironwork;

The Well Digger;

The "apprentice" of mini bus "Gbaka".

\section{In the transport}

The loading of heavyluggage in transport vehicles;

The activities of porters

\section{In works and public buildings}

The general activities of building and public works (digging, making the foundations, building walls, formwork, electrical and plumbing, pause frames, tiles and blankets, laying tiles, frames and windows, etc.)

The extraction of building materials;

The construction, reconstruction, maintenance, repair, alteration or demolition of any building or buildings and the site preparation and foundationsbeforesuchworks;

The manufacture of building materials;

Shipyardactivities.

National territory

Source:Decreen. 009of 19 January 2012.

Table A1:Decree n. 009 of 19 January 2012 on the determination of the list of dangerous work prohibited for children aged less than 18 years.

\begin{tabular}{|l|l|l|c|c|}
\hline \multicolumn{1}{|c|}{ Variables } & \multicolumn{1}{c|}{ Description } & Measure & Observation & Mean \\
\hline Characteristic of the household head & $\begin{array}{l}\text { Household expenditure } \\
\text { per capita per year } \\
\text { Household expensive (dep_m) }\end{array}$ & $\begin{array}{l}\text { Expenditure per } \\
\text { capita }\end{array}$ & 1338 & 156362 \\
\hline Level of education of the household head & $0=$ Uneducated & 1338 & 0.48 \\
\hline none & Uneducated & $1=$ Primary level & 1338 & 0.331 \\
\hline Primary (prim) & Primary level & & & \\
\hline
\end{tabular}




\begin{tabular}{|c|c|c|c|c|}
\hline Secondary (second) & Secondary level & $\begin{array}{l}2=\text { Secondary } \\
\text { level }\end{array}$ & 1338 & 0.173 \\
\hline Higher level (sup) & Higher level & 3= Higher level & 1338 & 0.015 \\
\hline \multicolumn{5}{|l|}{ Characteristic of the child } \\
\hline Age (age) & Number of years & Past year & 1338 & 9 \\
\hline Girls (girls) & Female child & $1=$ female & 1338 & 0.527 \\
\hline Boys (boys) & Male child & $0=$ male & 1338 & 0.472 \\
\hline \multicolumn{5}{|l|}{ School resource } \\
\hline Toilet (toil) & Availability of de toilet & $\begin{array}{l}1=\text { availability of } \\
\text { toilet }\end{array}$ & 1338 & 0.475 \\
\hline Canteen (cant) & Availability of canteen & $\begin{array}{l}1=\text { availability of } \\
\text { canteen }\end{array}$ & 1338 & 0.363 \\
\hline Drinking water point (eaup) & $\begin{array}{l}\text { Availability of drinking } \\
\text { water }\end{array}$ & $\begin{array}{l}1 \text { = availability of } \\
\text { drinking water }\end{array}$ & 1338 & 0.312 \\
\hline Electricity (elec) & Availability of electricity & $\begin{array}{l}1=\text { Availability } \\
\text { of electricity }\end{array}$ & 1338 & 0.717 \\
\hline Size of class (z-class) & $\begin{array}{l}\text { Number of students per } \\
\text { class }\end{array}$ & $\begin{array}{l}\text { Number of } \\
\text { students per class }\end{array}$ & 1338 & 46 \\
\hline
\end{tabular}

Source:Our calculations from the data ELTEPE 2010.

Table A2: Descriptive statisticsof the explanatory variables.

\begin{tabular}{|c|c|c|c|c|c|c|}
\hline & \multicolumn{2}{|c|}{ Whole } & \multicolumn{2}{c|}{ Girls } & \multicolumn{2}{c|}{ Boys } \\
\hline Variables & Work & School & Work & School & Work & School \\
\hline dep_m & $-0.145^{* *}$ & $0.173^{* * *}$ & -0.115 & $0.257^{* * *}$ & -0.158 & 0.107 \\
\hline & $(-2.88)$ & -3.45 & $(-1.40)$ & -3.49 & $(-1.76)$ & -1.37 \\
\hline prim & $-0.274^{* *}$ & $0.471^{* * *}$ & $-0.393^{* *}$ & $0.556^{* * *}$ & -0.345 & $0.573^{* * *}$ \\
\hline & $(-2.90)$ & -4.99 & $(-2.76)$ & -4.14 & $(-1.85)$ & -3.64 \\
\hline second & $-0.453^{* * *}$ & $0.440^{* * *}$ & $-0.455^{* *}$ & $0.571^{* * *}$ & $-0.597^{* *}$ & $0.470^{* *}$ \\
\hline & $(-4.34)$ & -4.21 & $(-2.66)$ & -3.69 & $(-2.59)$ & -2.79 \\
\hline sup & $-0.486^{* * *}$ & $0.720^{* * *}$ & $-0.531^{* *}$ & $0.764^{* * *}$ & $-0.621^{* *}$ & $0.716^{* * *}$ \\
\hline & $(-4.21)$ & -6.28 & $(-2.88)$ & -4.8 & $(-2.67)$ & -3.62 \\
\hline toil & 0.102 & $-0.199^{*}$ & 0.107 & -0.098 & 0.224 & $-0.335^{*}$ \\
\hline & -1.03 & $(-2.03)$ & -0.58 & $(-0.66)$ & -1.29 & $(-2.12)$ \\
\hline cant & $-0.503^{* * *}$ & $1.038^{* * *}$ & $-0.602^{* * *}$ & $1.374^{* * *}$ & $-0.484^{* * *}$ & $0.792^{* * *}$ \\
\hline & $(-5.44)$ & -11.37 & $(-3.93)$ & -9.62 & $(-3.44)$ & -5.93 \\
\hline eaup & -0.086 & $0.215^{* *}$ & -0.045 & 0.016 & $-0.328^{*}$ & $0.380^{* *}$ \\
\hline & $(-0.91)$ & -2.26 & $(-0.34)$ & -0.12 & $(-1.97)$ & -2.49 \\
\hline
\end{tabular}




\begin{tabular}{|c|c|c|c|c|c|c|}
\hline & $(-2.45)$ & -1.82 & $(-1.13)$ & -2.03 & $(-4.12)$ & -4.38 \\
\hline \multirow[t]{2}{*}{ z-class } & 0.087 & -0.221 & 0.007 & -0.102 & -0.182 & 0.249 \\
\hline & -0.65 & $(-1.65)$ & -0.03 & $(-0.50)$ & $(-0.79)$ & -1.18 \\
\hline \multirow[t]{2}{*}{ age } & $-0.414^{* * * *}$ & $0.186^{* *}$ & $-0.536^{* * * *}$ & 0.139 & $-0.456^{* * *}$ & 0.15 \\
\hline & $(-5.93)$ & -2.77 & $(-5.07)$ & -1.49 & $(-3.79)$ & -1.36 \\
\hline \multirow[t]{2}{*}{ age2_100 } & $1.080^{* *}$ & $-0.905^{* *}$ & $1.547^{* *}$ & -0.81 & $1.378^{*}$ & -0.613 \\
\hline & -3.08 & $(-2.59)$ & -3.03 & $(-1.69)$ & -2.31 & $(-1.06)$ \\
\hline \multirow[t]{2}{*}{ girls } & $0.209^{* *}$ & $-0.181^{*}$ & & & & \\
\hline & $(-1.07)$ & -1.79 & $(-1.22)$ & -1.21 & -0.81 & -0.62 \\
\hline \multirow[t]{2}{*}{ cons } & $-2.089^{* *}$ & -0.588 & $-2.995^{*}$ & $-2.294^{*}$ & -2.05 & -0.0598 \\
\hline & $(-2.63)$ & $(-0.77)$ & $(-2.26)$ & $(-2.02)$ & $(-1.67)$ & $(-0.05)$ \\
\hline Log likelihood & -877.163 & & -462.02 & & -373.923 & \\
\hline Wald chi2(26) & 411.61 & & 260.92 & & 161.13 & \\
\hline Prob>chi2 & 0 & & 0 & & 0 & \\
\hline \multirow[t]{2}{*}{ rho } & $-0.979 * * *$ & & $-0.973 * * *$ & & $-0.970 * * *$ & \\
\hline & $(-218.34)$ & & $(-134.74)$ & & $(-94.14)$ & \\
\hline \multicolumn{7}{|l|}{$\begin{array}{c}\text { Likelihood-ratio } \\
\text { test of rho=0 }\end{array}$} \\
\hline Chi2 (1) & 643.1 & & 347.218 & & 293.003 & \\
\hline Prob>chi2 & 0 & & 0 & & 0 & \\
\hline Observation & \multicolumn{2}{|c|}{1338} & \multicolumn{2}{|c|}{706} & \multicolumn{2}{|c|}{632} \\
\hline
\end{tabular}

Source:Our calculations from the data ELTEPE 2010.

Table A3:The estimation resultsof thebivariateprobitof the determinantsof child labor.

$t$ statistics in parentheses

${ }^{*} p<0.05,{ }^{* *} p<0.01,{ }^{* * *} p<0.001$

\begin{tabular}{|c|c|c|c|c|c|c|}
\hline & \multicolumn{2}{|c|}{ Whole } & \multicolumn{2}{c|}{ Girls } & \multicolumn{2}{c|}{ Boys } \\
\hline Variables & Pr (Work=1) & Pr (School=1) & Pr (Work=1) & Pr (School=1) & Pr (Work=1) & Pr (School=1) \\
\hline dep_m & -0.0305 & 0.0523 & -0.0246 & 0.0778 & -0.0289 & 0.0298 \\
\hline prim & -0.0577 & 0.1427 & -0.0839 & 0.1686 & -0.0632 & 0.1588 \\
\hline second & -.0 .0954 & 0.1332 & -0.0974 & 0.173 & -0.1096 & 0.1303 \\
\hline sup & -0.1023 & 0.2178 & -0.1135 & 0.2318 & -0.1139 & 0.1984 \\
\hline toil & 0.0214 & -0.0603 & 0.0228 & -0.0299 & 0.041 & -0.0927 \\
\hline cant & -0.1057 & 0.3142 & -0.1288 & 0.4167 & -0.0887 & 0.2197 \\
\hline eaup & -0.0182 & 0.0649 & -0.0097 & 0.005 & -0.0601 & 0.1054 \\
\hline elec & -0.0588 & 0.0619 & -0.0487 & 0.1058 & -0.1535 & 0.2175 \\
\hline t-classe & 0.0184 & -0.0668 & -0.0025 & 0.0309 & -0.0334 & 0.0692 \\
\hline age & -0.0872 & 0.0564 & 0.1146 & -0.042 & 0.0836 & -0.0415 \\
\hline age2_100 & 0.2273 & -0.274 & -0.3308 & 0.2456 & -0.2528 & 0.17 \\
\hline sexe & 0.0439 & -0.0549 & & & & \\
\hline
\end{tabular}

Source:Our calculations from the data ELTEPE 2010.

Table A4:Marginal effect from the estimation of bivariate probit. 